\title{
LINKING FAIRNESS PERCEPTIONS TO TURNOVER INTENTIONS IN GLOBAL SHARED SERVICE CENTERS
}

\author{
Mehmet A. ORHAN \\ Vrije Universiteit Brussel, Belgium
}

\begin{abstract}
The motivation for this study was to investigate how workplace fairness can have an impact on shared service employees' job satisfaction, organizational commitment, identification and turnover intention. Even though we read plenty of studies in organizational matters, none was specifically addressed the behavioral issues encountered by the employees of global shared service centers (SSC).

As a practical and excellent strategy for workforce utilization, global shared service organizations could promote the benefits of cultural diversity by distributing and allocating resources fairly. The fundamental objective of this research is to present a roadmap to assist SSC executives grasp how to improve and maintain employees' job satisfaction and encourage them to stay in their career. This would minimize one of the well-known, hardest challenges of SSCs: high employee turnover ratios, which are wasteful to the organization's valuable human resources.
\end{abstract}

Keywords: Shared service centers, turnover, satisfaction, fairness, commitment, identification

\section{Introduction}

Over the last decades, with increased economic and technological competition, companies felt the pressure of sustaining profitability by reducing costs: reducing it without giving up efficiency. The changes in communication channels and as well as the mobility of the global workforce made for multinational companies possible to centralize certain functions, to meet efficiency, to reduce costs (Janssen and Joha, 2008; Curseu et al., 2008; Hertel et al., 2005; Kirkman et al., 2004; Montoya-Weis et al., 2001) and consequently to design organizations called shared service centers. One of the requirements that make international companies successful and that make them remaining competitive is the overall standardization of the operations. So, the shared service center (SSC) organization concept was born, since the global companies preferred to initiate the implementation in order to benefit from cost reduction and improved efficiency (Aksin and Masini, 2008).

"Shared services" appeared as an idea. It included whole mixture of the recent management ap-
proaches; lean management, business process re-engineering, TQM, outsourcing, off-shoring, busi-
ness process outsourcing, which all allow companies to focus on efficiency. 'Shared services' brings
the efficiency and effectiveness into one pivotal location, by combining some activities that are per-
formed in common across all departments or locations of an organization. These locations are the cen-
ters dedicated to serve local business units and challenged to establish as separate, effective, low-cost
and centralized business units (Bergeron, 2003). These business units carry the responsibility of man-
aging and accomplishing some daily operational tasks. With this leverage, senior executives and upper
management could focus on more strategic activities and corporate matters rather than on repetitive
operational tasks (Davis, 2005). However, while doing that, executives ought to be able to understand
what are the key strategic activities or the core competences that have direct impact on the organiza-
tion, and what are the shared tasks whose migration will increase the efficiency and effectiveness by
reducing cost. Therefore, as SSCs are mainly associated with cost reduction (Norling, 2001). On one
hand, the pressure of increased efficiency desires; on the other hand, cost reduction obligations created
tough challenges for SSC managers and strategy executors.
Quite often, executives exaggerate the hopes that a SSC will bring up to the organization (Ulbrich,
2006) and sometimes it goes further than the reality. First of all, it is not as easy to achieve all benefits
of shared service centers as it is thought (Janssen and Wagenaar, 2004). One of those issues is the
trade-off between the cost reduction achieved via economies of scale and the responsiveness to the
customized need of business units receiving the service (Bergeron, 2003). Various needs and service
expectations may create a barrier for this customization. Then the service will no longer lead to a 
benefit for the business unit receiving the service, if it has the feeling that services do not satisfy the needs. Thus, the planning process of implementing a SSC should be well managed at a senior and strategic level in organizations (Janssen and Joha, 2006). Unfortunately, the operational challenges are not the only ones that need to be taken into consideration. There are more vital ones for the long-term survival of SSC. One of the arguments is from the human resources planning point of view. It is believed that SSCs are still dealing with the brutal issues under the domain of human resources; fail to create further future career path for their employees, keep them satisfied, and maintain the attrition rate as low as possible. Otter (2003, p.2) claimed the following:

"Service centers create significant challenges for career planning, job satisfaction and compensation, and are often blighted by high employee turnover". Even though the real statistics are hard to get, it is believed that today's employee turnover rates reached is relatively far beyond than expected (Koenen, 2006).

Today, organizations of all sizes -in terms of revenue, employees and operating units- are realizing shared services benefits (Sutcliff, 2003). SSCs are also designed to promote innovation (Craike and Singh, 2006) by establishing corporate-level functional groups to provide specialized services (Kaplan and Winby, 2009). With this initiative, companies also aim to optimize operational costs and knowledge creation from diverse, multiple international operations (Lemagnen, 2005). Knowledge creation can be gradually achieved if these shared service organizations employ a skilled, diverse workforce and keep employees stay in their career. Otherwise, employee turnover would be very costly (Hardy et al., 2002), as when employees leave, shared service organizations lose not only the investment made in trainings, but also the cost of knowledge departing that had been acquired by that employee. Hence, economies of scale becomes than harder to reach.

In order to maintain efficiency and productivity companies must give to utmost importance to knowledge transfer among the employees and therefore must retain long-term relations with skilled employees. Employee turnover should be a key element that SSCs ought to take into account at first hand. Studies have proven that perceived fairness of decisions about performance appraisals, promotions, and resource allocations can impact employee commitment, satisfaction and job performance (Cowherd and Levine, 1992; Fryxell, 1992; Greenberg, 1990; Konovsky and Cropanzano 1991). McFarlin and Sweeney (2001) also argue that multinational corporations need to be concerned with justice issues when implementing their international strategies.

\section{LITERATURE REVIEW}

In terms of organizational structures, shared service organizations are somewhere between a full hierarchical model and market-driven focus model, which are considered as two extremes (Jansen and Joha 2008). The level of control in traditional organizations is significantly high, whereas the understanding of the market control is minimal. On the other hand, in case of outsourcing, there is no such thing like hierarchical control, as the service provider has no organizational relations with corporations. Control and source are still maintained as high with increased market control, improved efficiency, and high quality service levels. Each and every day improvements in the information and communication tools and the flexibility in the organizational structure enabled local and global SSCs to grow. This growth is caused more diverse work groups getting together, which leads greater complication to manage.

Employees' observations and feelings about the fairness in the workplace are called "organizational justice" (Greenberg, 1987). In every organization, it is expected that each employee to be treated fairly. The answer to the question of "Why are employees' feelings about the fairness in the workplace important?" is the allocation and distribution of resources will have a direct impact on several different work-related motives; organizational outcomes such as performance, as well as employees' attitudes and behaviors (Moorman, 1991). Thus, managers and policymakers need to ensure that resources are distributed without any bias so that employees can perform flawlessly.

Organizational commitment can be defined as "the degree to which people identify with the organization that employs them" (Wagner and Hollenbeck, 2005, p.111). Commitment is often associated with loyalty, compliance and enthusiasm to accomplish task-related goals in an organization (Meyer and Allen, 1997). This leads to some level of emotional attachment to the organization.

Almost every commitment scales evaluates affective side of it, which is an employee's identification of organizational objectives as his or her own (Allen and Meyer, 1990). It is also argued that organiza- 
tional commitment symbolizes a set of emotional responses, which are fairly universal for employees. It is believed that everyone should possess some emotional feelings to some extent for the organization which is worked at (Colquitt et al., 2001).

The dynamic playground of organizations does not allow companies to stabilize all the business ingredients with respect to resources. 'Human resources', as a function, is among the most dynamic ones, frequent career switches are accepted as reasonable. However, an increased understanding of what is required to maintain an efficient, productive workforce with high satisfaction and commitment levels is becoming a must for companies (Smith, 1992). Job satisfaction can be defined as "a pleasurable or positive emotional state resulting from the appraisal of one's job or job experiences" (Locke, 1976, p.1300). It has been identified as one of the key organization variables influencing other crucial attitudinal and behavioral results like performance, either decision or intention leave or some level of absenteeism (Iaffaldano and Muchinsky, 1985; Judge et. al., 2001; Locke, 1976).

Mael and Ashforth (1992, p.103) define organizational identification as "a perceived oneness with an organization and the experience of the organization's successes and failures as one's own". It is a form of emotional attachment to the organization which is very closely related to organizational commitment (Dutton et. al., 1994).

It is believed that the best precursor of turnover is turnover intention (Allen et. al, 2005; Griffeth et. al., 2000, Lee and Mowday, 1987, O'Reilly and Caldwell, 1981). Turnover intention is defined by Mobley (1977) as a consideration of quitting the job in a close future as a next step after experienced dissatisfaction.

Organization studies investigated the relationships of justice in the workplace and individuals' feelings about their work environment and their decision mechanism to depart from organization. Amongst them, several researchers found meaningful and significant relations between satisfaction, attachment to the organization and turnover intent (Tett and Meyer, 1993; O'Reilly and Caldwell, 1980; Ferris and Aranya, 1983; Stumpf and Hartman, 1984). Conversely, equity-justice theories proposed the following: when employees evaluate results as unfair in the organization, they became less satisfied compared to those who assess the environment as fairer (Aryee et al., 2002) and as a result, there emerges negative behavioral decisions, such as intention to leave the organization (Spector, 1985). It can be verified by several studies that intention to leave the organization is the strongest predictor of leaving the organization (Allen et. al, 2005; Griffeth et. al., 2000, Lee and Mowday, 1987; Michaels and Spector, 1982). Literature also includes a large number of studies linking the turnover intention concept with commitment to organization (Joo, 2010; Arnold and Feldman, 1982) as well as with identification (De Maura et. al, 2009; Cole and Bruch, 2006).

\section{CONTEPTUAL MODEL AND RESEARCH HYPOTHESES}

\section{Conceptual Model Development}

Our aim with this study is to highlight the organizational issues experienced at SSC. By doing so, we will be identifying four research questions and bringing up a clarification on how organizational variables such as satisfaction, commitment, identification and turnover relate with justice in the workplace in global shared services center environment. To address the purpose of this study, the major research questions addressed by this study are;

(1) "How do organizational justice perceptions relate to the job satisfaction of employees?"

(2) "How do organizational justice perceptions relate to the organizational commitment and identification of employees?"

(3) "How do job satisfaction perceptions relate to the organizational commitment of employees?"

(4) "How does fairness in the workplace have impact on employees' intention to leave the organization?"

The answers to these four questions will be the basis of research problem used to point out the relations between the organizational variables and justice perceptions in our model. Our model, as indicated in Figure 1, is designed to investigate the associations between the organizational constructs, which are previously tested theoretically and empirically, as presented in Literature Review part. 


\section{Fig. 1 Conceptual Model}

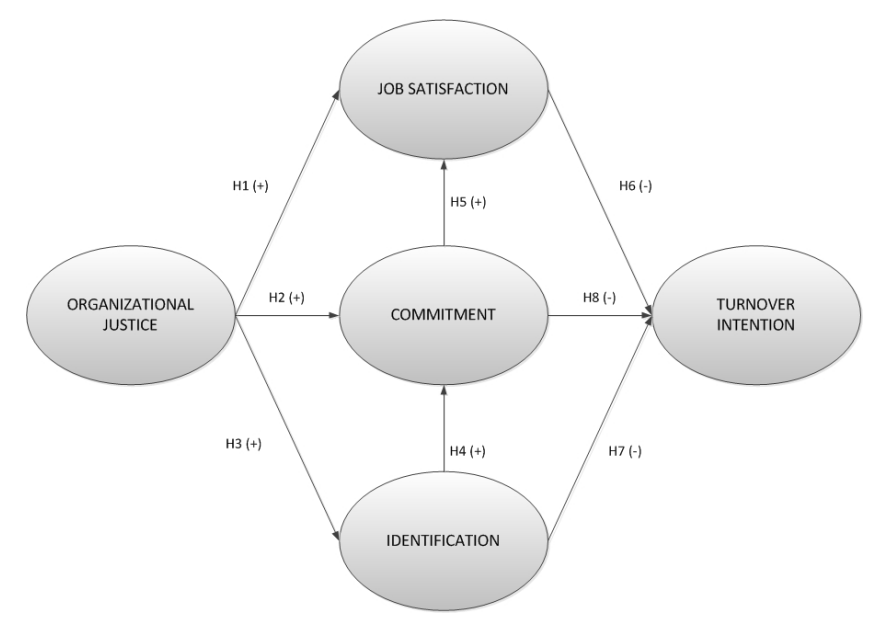

\section{Research Hypotheses}

Based on the conceptual model developed, the following hypotheses are formulated:

H1: When the organizational environment is perceived as overall fair, then employees feel more satisfied with their job.

H2: When the organizational environment is perceived as overall fair, employees stay committed to the organization.

H3: When the organizational environment is perceived as overall fair, employees feel as belonging to the organization.

H4: Employees commitment to the shared service organization is positively associated with their identification to the shared service center.

H5: Employees' job satisfaction is positively associated with their commitment to the shared service center.

H6: Employees' intention to leave the work is negatively correlated with their job satisfaction.

H7: Employees' intention to leave the organization is negatively correlated with the identification to the shared service center.

H8: Employees' intention to leave the organization is negatively correlated with their commitment to the shared service center.

\section{RESARCH METHOD}

\section{Sample and Data Collection}

The questionnaire is designed on the online survey software tool and distributed over the Internet. The data are collected via the website (http://www.surveymonkey.com/s/CLZ7PJ3). This provided a great deal of validity and flexibility. The survey has been distributed via the group functionality of Linkedin.com. All professional network groups related with shared service centers are scanned and reviewed. Then, the survey has been distributed via online messages with several reminders. Over 200 people who currently work at a shared service organization are reached and requested to fill out the survey. 132 of them responded to the survey. The highest level of validity is maintained, as the online survey is designed in a way that it did not allow skipping any question or submitting blank, missing, invalid answers. In total, 124 complete surveys are collected. Descriptive findings are presented on the Appendix I.

Data analyses are performed by utilizing several computer applications. Data entry and demographic statistics are done via Microsoft Excel. Basic statistical analyses such as descriptive analysis and reliability tests are utilized via SPSS 11. For path analyses, AMOS 16 is used. Path diagrams are redrawn on Microsoft Visio for visual effectiveness. 


\section{Scale Development}

In total, five main scales were used in our research to measure the subject variables in SSCs. These are the measures of employees' justice perceptions, commitment and identification to organizations, intention to leave the organization and finally their job satisfaction. 5-point Likert scale is used for all measures.

Overall fairness in the workplace has been measured with three sub-scales developed by Niehoff and Moorman (1993). These are distributive justice, procedural justice, and interactional justice subscales, the most widely and most frequently used scales for measuring fairness perceptions in the workplace. The scales are designed on the basis of Moorman's study (1991) where reliability scores are found over .90 for each construct.

Organizational commitment has been measured with the instrument called Organizational Commitment Questionnaire (OCQ) developed by Mowday, Steers and Porter (1979). The original OCQ consists of 15 statements. The shortened version is used with 4 items, which is widely used in the literature.

Mael and Ashforth's (1992) scale is used to measure employees' identification to shared service centers as well as to the entire corporation. Originally six-item developed, five-item scale is utilized and adjusted for assessing the degree of identification.

Employees' intention to leave the organization was measured with 4-item scale designed by Kelloway, Gottlieb, and Barham's (1999).

The oldest scale used in our study is one item job satisfaction scale developed by Scarpello and Campbell in 1983. The question is worded as: "Overall, how satisfied are you with your job?". One itemscale of job satisfaction used as a measure to identify employees' job satisfaction levels drew too much attention and instigated discussions, questioning validity and reliability of the scale in the literature (Nagy, 2002; Wanous et. al., 1997). Nagy (2002) merited the use of one-item scale due to several advantages such as less time-consumption to respond, and easy to setup, as well as increased validity. Wanous et al., (1997) also argued that one-item scales of job satisfaction are good enough and highly correlated with multiple-item scales, and preferable as overall satisfaction measure over the ones consisting of more than single items.

\section{EMPIRICICAL ANALYSES AND RESULTS}

\section{Descriptive Statistics and Measurement Model}

Correlations between procedural justice (PJ), interactional justice (IJ), distributive justice (DJ), commitment to the SSC (COMS), identification to the SSC (IDS), satisfaction (JS) and turnover intention (TI) have been computed and presented in Table 1. Pearson correlation analysis has been performed. As seen on the correlation matrix below, most of the variables are significantly correlated.

Table 1. Means, Standard Deviations, Correlations

\begin{tabular}{|c|c|c|c|c|c|c|c|c|c|c|}
\hline Variable & Mean & St. Dev & 1 & 2 & 3 & 4 & 5 & 6 & 7 & 8 \\
\hline 1. Employment (months) & 44.10 & 38.31 & - & & & & & & & \\
\hline 2. Age & 31.97 & 5.90 & $0.459^{\star *}$ & - & & & & & & \\
\hline 3. DJ & 3.29 & 0.93 & 0.169 & 0.108 & - & & & & & \\
\hline 4. PJ & 3.20 & 1.06 & $0.235^{\star \star}$ & 0.130 & $0.603^{* *}$ & - & & & & \\
\hline 5. IJ & 3.43 & 1.08 & 0.159 & 0.076 & $0.634^{* *}$ & $0.788^{\star *}$ & - & & & \\
\hline 6. COMS & 3.10 & 1.21 & 0.105 & $0.275^{\star *}$ & $0.495^{\star *}$ & $0.592^{* *}$ & $0.503^{\star *}$ & - & & \\
\hline 7. IDS & 2.97 & 1.14 & $0.229^{*}$ & $0.320^{\star *}$ & $0.474^{\star *}$ & $0.505^{\star *}$ & $0.469^{* *}$ & $0.851^{* *}$ & - & \\
\hline 8. $\mathrm{TI}$ & 3.18 & 1.33 & $(0.190)^{\star}$ & $(0.180)^{*}$ & $(0.511)^{\star *}$ & $(0.516)^{\star *}$ & $(0.414)^{\star *}$ & $(0.716)^{\star *}$ & $(0.696)^{\star *}$ & - \\
\hline 9. JS & 3.12 & 1.21 & 0.127 & 0.165 & $0.636^{* *}$ & $0.636^{* *}$ & $0.578^{* *}$ & $0.775^{\star *}$ & $0.707^{* *}$ & $(0.768)^{* *}$ \\
\hline
\end{tabular}

Table 2 provides detailed mean analyses. The analyses stratified into demographic structures; region, gender, educational background, job role, years of employment and age. The highest scores within the groups are shown red (bold), and the lowest ones are as blue (italic). Further analyses of means by survey items and the reliability analyses of each construct are presented in Table. B in Appendix II. 
Table 2. Detailed Mean Analyses

\begin{tabular}{|c|c|c|c|c|c|c|}
\hline & \multicolumn{5}{|c|}{ Means } & \multirow[b]{2}{*}{ Count } \\
\hline Region & OJ & COMS & IDS & TI & JS & \\
\hline ASIA & 3.42 & 2.92 & 2.88 & 3.27 & 3.21 & 24 \\
\hline EE & 3.27 & 3.02 & 2.83 & 3.29 & 3.13 & 46 \\
\hline WE & 3.31 & 3.30 & 3.28 & 2.87 & 3.24 & 33 \\
\hline Others & 3.38 & 3.15 & 2.92 & 3.35 & 2.81 & 21 \\
\hline \multicolumn{7}{|l|}{ Sex } \\
\hline Female & 3.31 & 3.09 & 0.02 & 3.39 & 2.95 & 80 \\
\hline Male & 3.34 & 3.10 & 3.00 & 3.07 & 3.21 & 44 \\
\hline \multicolumn{7}{|l|}{ Education } \\
\hline Associate or lower & 3.43 & 3.57 & 3.35 & 3.15 & 3.27 & 15 \\
\hline Bachelors & 3.37 & 3.02 & 2.82 & 3.20 & 3.13 & 54 \\
\hline Masters or higher & 3.27 & 2.76 & 2.77 & 2.91 & 2.78 & 55 \\
\hline \multicolumn{7}{|l|}{ Job Role } \\
\hline Admin / Front & 3.44 & 3.04 & 2.87 & 3.09 & 3.33 & 24 \\
\hline Professional & 3.19 & 2.79 & 2.64 & 3.53 & 2.81 & 54 \\
\hline Supervisory & 3.09 & 3.01 & 2.97 & 3.28 & 2.84 & 25 \\
\hline Managerial & 3.84 & 4.05 & 3.97 & 2.27 & 4.00 & 21 \\
\hline \multicolumn{7}{|l|}{ Years of Service } \\
\hline 0 - 2 years & 3.24 & 3.15 & 2.99 & 3.32 & 3.13 & 30 \\
\hline 2 - 4 years & 3.27 & 3.02 & 2.85 & 3.25 & 3.06 & 54 \\
\hline 4 - 6 years & 3.34 & 3.06 & 2.96 & 3.22 & 3.07 & 28 \\
\hline$>6$ years & 3.82 & 3.38 & 3.52 & 2.46 & 3.50 & 12 \\
\hline \multicolumn{7}{|l|}{ Age } \\
\hline $25-28$ & 3.29 & 2.68 & 2.54 & 3.13 & 2.77 & 44 \\
\hline $29-32$ & 3.16 & 2.83 & 2.74 & 3.31 & 2.89 & 36 \\
\hline $33-36$ & 3.32 & 3.22 & 3.03 & 2.89 & 3.21 & 19 \\
\hline $37-40$ & 3.94 & 3.54 & 3.40 & 2.52 & 3.79 & 14 \\
\hline$>41$ & 3.29 & 3.91 & 3.85 & 3.02 & 3.36 & 11 \\
\hline Ave/Total & 3.33 & 3.10 & 2.97 & 3.18 & 3.12 & 124 \\
\hline
\end{tabular}

Male participants' perception of fairness, commitment to their organization, identification and their satisfaction level seemed to be higher than their female colleagues at shared service centers but this has not been supported with any statistical significance based on our independent t-tests (See Table . $\mathrm{C}$ in Appendix III). In terms of education, the least satisfied group is found to be employees with at least a Master degree. According to job role, managers are reported as the highest satisfied group in our survey.

\section{Hypotheses Testing}

As discussed in Conceptual Model Development part, four major research questions are determined to answer our hypotheses structured on the basis of previous theoretical studies. Figure 2 exhibits the path analyses conducted for the structural equation model. Each path is addressing the hypothesis that were found as significant at $\mathrm{p}<.001$.

Fig.2 Path Analysis of the Conceptual Model

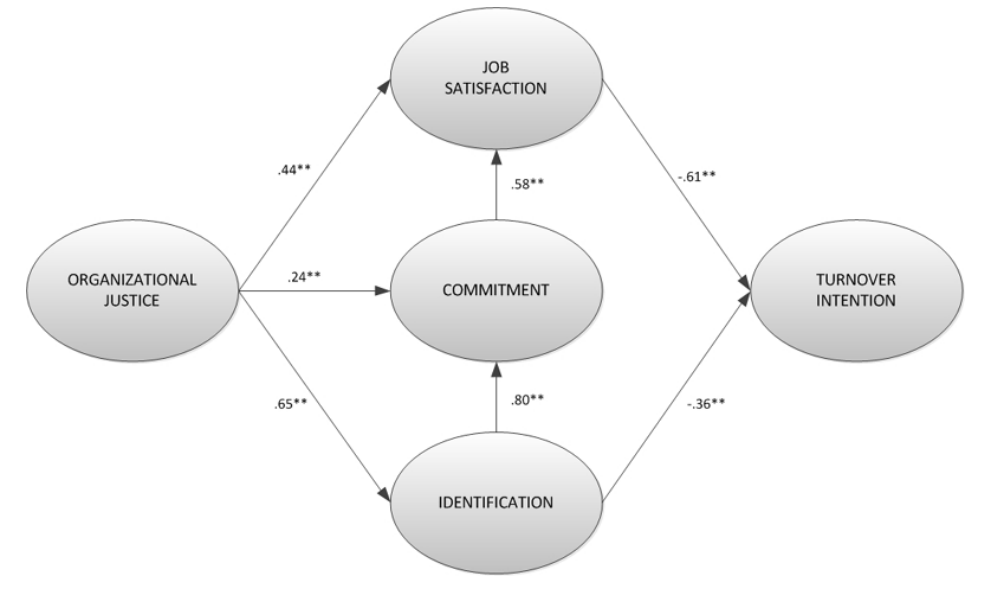


Table. 3. Goodness of Fit Statistics of the Conceptual Model

\begin{tabular}{llllllll}
\hline Goodness of Fit Statistics & $\chi 2 / \mathrm{df}$ & RMSEA & GFI & AGFI & NFI & CFI & RMR \\
\hline Acceptable Model & $<3$ & $<.08$ & $>.9$ & $>.8$ & $>.9$ & $>.9$ & $<.08$ \\
Conceptual model & 1.08 & .026 & .989 & .947 & .993 & .999 & .021
\end{tabular}

In addition to our path analysis, where we showed the direct relations between the constructs, we analyzed the indirect effects in order to suggest further explanation between the variables that had indirect effects also called mediated effects. As being one of the advantages, structural equation modelling allows to identify mediation instead of testing each linkage between dependent and independent variables.

According to Table 5, justice has a strong, negative indirect effect on the employees' decisions to leave shared service organizations. As fairness had direct effects on satisfaction, commitment and identification, these variables have mediated the association between justice and intention to leave. Job satisfaction is loaded with the highest effects, as it is mediated the relation between justice and commitment with turnover intention. Identification also mediated the relationship between organizational justice and commitment, as well as with turnover intention.

It is also discussed in hypotheses testing that organizational commitment is not directly linked to intent to leave. Nonetheless, satisfaction became a mediator in the relation to turnover intention, underlying the indirect negative effect of commitment to shared service organization.

Total effects, direct effects and indirect effects of the constructs are indicated below:

Table.4. Direct Effects

\begin{tabular}{|c|c|c|c|c|}
\hline & OJ & IDS & COMS & JS \\
\hline IDS & .654 & - & - & - \\
\hline COMS & .236 & .803 & - & 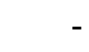 \\
\hline JS & .442 & .000 & .577 & - \\
\hline TI & .000 & -.356 & .000 & -.607 \\
\hline
\end{tabular}

Table. 5. Indirect Effects

\begin{tabular}{lrrrr}
\hline & OJ & \multicolumn{1}{r}{ IDS } & COMS & JS \\
\hline IDS & - & - & - & - \\
COMS & .525 & - & - & - \\
JS & .440 & .464 & - & - \\
TI & -.767 & -.281 & -.350 & - \\
\hline
\end{tabular}

Table. 6. Total Effects

\begin{tabular}{lrrrr}
\hline & OJ & IDS & COMS & JS \\
\hline IDS & .654 & - & - & - \\
COMS & .762 & .803 & - & - \\
JS & .881 & .464 & .577 & - \\
TI & -.767 & -.637 & -.350 & -.607 \\
\hline
\end{tabular}




\section{DISCUSIONS AND IMPLICATIONS}

\section{Theoretical Discussion and Limitations}

In general, our study presented excellent internal reliability results of each construct measured. All sub - limitation, we can address the design of data collection in general. Quite often, we might fail to understand the causality route because of the nature of cross-sectional data collection, as they were done at once. Thus, the relationship between the constructs over time cannot be identified. Lastly, the sample size needs to be larger in order to avoid measurement biases. Although we obtained almost a perfect fit in our model, the generalizability is still under question. Larger sample size ( $>200)$ could be recommended and may be more desirable, as it will minimize the errors of estimation in the model.

Although we highlighted the fact that there is a redundancy in the studies available on the relational review on the fairness perception, and its relation with other organizational variables, this thesis is the first and only research in the literature to elaborate the organizational issues in shared service organizations environment, which is pretty different than the conventional type of organizations. Multinational workforce forms a diverse background of employees in global shared service organizations. To cope with this plurality surely becomes a critical issue for global shared service executives. Thus, a further study on the cultural differences in detail in comparison of employee attitudes and behaviors might also be recommended.

\section{Conclusions and Practical Implications}

Fairness is a major challenge for organizations as well as for managers. It is becoming more and more challenging ever since companies went global, different cultures started to work more often together. It is becoming crucial for leaders to design and to execute policies, procedures and guidelines fairly, to distribute resources fairly, and also to interact with subordinates fairly, of course, if leaders aim to keep employees satisfied, and committed, consequently make them stay in their career. Based on several studies, we examined that SSC leaders suffer from the severe ratios of employee turnovers, and have difficulty to assure that accumulated knowledge is sustained within the organization for processes centralization, and for providing better service.

From the employee perspective, fairness in the workplace is essential, and is a must. Almost every single research related with justice under the organizational behavior domain proved that fairness perception is a great predictor of employees' work attitudes, behaviors and decisions. We also concluded that SSC employees' attitudes, behaviours and decisions are heavily dependent on the perception of the justice distributed, executed and interacted in the organization.

As discussed in the introduction part, the fundamental objective of our research was to present a model that investigates the role of fairness in the shared service environment with other work-related feelings, perceptions, attitudes, behaviors and their decisions to leave. With the outcome of this research, we have provided a meaningful and broader perspective on SSC employees' positive perception of the justice implications in the workplace promoting their identification, commitment and satisfaction, and last but not least their final-say whether to stay in their existing career or leave. This means the fairer the work environment is, the more satisfied, the more committed are the employee. Based on the total effects of our path analysis, our results also proved that organizational justice is perceived as the most crucial path influencing employees' job satisfaction in the shared service environment. The same total effects also reflected that employees' turnover intention does highly rely on the justice perception in the organization. Besides the empirical evidences, which shed some light on the neglected issues of the organizational and behavioral sides of the shared service organizations, our study presented a theoretical direction for future studies.

In conclusion, we believe that our research proposes a great deal of advantages that can be used as a roadmap. It will assist to SSC managers to recognize how fairness can improve employees' job satisfaction, commitment and identification to the organization. As a result, organizational justice will play a central role encouraging employees to stay in their career. This would minimize one of the wellknown, hardest challenges of SSCs: high employee turnover ratios that are wasteful to the organization's valuable human resources. 


\section{REFERENCES}

Aksin, O.Z. and Masini, A (2008), "Effective strategies for internal outsourcing and offshoring of business services: An empirical investigation”, Journal of Operations Management, Vol.26(2), p. 239256 ,

Allen N.J., Meyer, J.P., (1990), "The measurement and antecedents of affective, continuance and normative commitment”. Journal of Occupational Psychology, Vol.63, p.1 -18.

Allen D.G., Weeks, K.P., and Moffit, K.R., (2005), "Turnover intentions and voluntary turnover: The moderating roles of self-monitoring, locus of control, proactive personality, and risk aversion". Journal of Applied Psychology, Vol.90(5), p.980 -990

Arnold, H. J., Feldman, D. C. (1982), "A multivariate analysis of the determinants of job turnover", Journal of Applied Psychology, Vol.67,(3), p.350-360.

Aryee, S. Budhwar, P.S. Chen, Z.X. (2002), "Trust as a mediator of the relationship between organizational justice and work outcomes: Test of a social exchange model", Journal of Organizational Behavior, Vol.23 (3) p.267-285

Bergeron, B. (2003), Essentials of Shared Services, Wiley Hoboken, NJ. Cole, M.S., Bruch, H. (2006), "Organizational identity strength, identification, and commitment and their relationships to turnover intention: Does organizational hierarchy matter?" Journal of Organizational Behavior, Vol.27, Sp.585-605

Colquitt, J. A, Conlon, D.E, Wesson, M. Y, Porter, C, and Ng, K.Y, (2001), "Justice at the millennium: A meta-analytic review of 25 years of organizational justice research", Journal of Applied Psychology, Vol.86 (3), p425

Cowherd, D.M., Levine D.I (1992), "Product quality and pay equity between lower-level employees and top management: An investigation of distributive justice theory", Administratively Science Quarterly, Vol.37(2) p.302-320

Craike, A., Singh, P.J. (2006), "Shared services: A conceptual model for adoption, implementation and use", International Journal of Information Systems and Change Management Vol 1(3), p 223240

Cropanzano, R., Greenberg, J. (1997). Progress in organizational justice: Tunneling through the maze. In C. Cooper \& I. Robertson (Eds.), International review of industrial and organizational psychology (p. 317-372). New York: Wiley.

Curseu P.L., Schalk, R. Wessel, I. (2008), "How do virtual teams process information? A literature review and implications for management” Journal of Managerial Psychology, Vol. 23 (6), p.628 - 652

Davis T.R.V. (2005), "Integrating shared services with the strategy and operations of MNEs" Journal of General Management Vol.31 (2) p.1-17

De Moura, G. R., Abrams, D., Retter, C., Gunnarsdottir, S. \& Ando, K. (2009). "Identification as an organizational anchor: How identification and job satisfaction combine to predict turnover intention", European Journal of Social Psychology, Vol.39(4), p. 540-557.

Ferris, K. R., Aranya, N. (1983), “A comparison of two organizational commitment scales”, Personnel Psychology, Vol. 36, p.87-98.

Fryxell, G.E. (1992), "Perception of justice afforded by formal grievance systems as predictors of a belief in a just workplace", Journal of Business Ethics, Vol. 11(8) p.635-647

Greenberg, J. (1987), “A taxonomy of organizational justice theories”, The Academy of Management Review, Vol.12, p.9-22.

Greenberg, J. (1990), “Organizational justice: Yesterday, today and tomorrow”, Journal of Management, Vol 16(2) p. 399-432

Griffeth, R. W., Hom, P. W. \& Gaertner, S. (2000). "A meta-analysis of antecedents and correlates of employee turnover: Update, moderator tests, and research implications for the next millennium". Journal of Management, Vol. 26,p.463-488 
Hardy, G.E., Woods, D., Wall, T.D., (2002), "The impact of of psychological distress on absence from work", Journal of Applied Psychology, Vol.88, p.306-314.

Hertel, G., Geister, S. and Konradt, U. (2005), "Managing virtual teams: A review of current empirical research", Human Resource Management Review, Vol. 15, p. 69-95.

Iaffaldano, M., \& Muchinsky, P. M. (1985). "Job satisfaction and job performance: A meta-analysis". Psychological Bulletin, Vol. 97(2), p.251-273.

Janssen, M., Joha, A., (2006), "Motives for establishing shared service centers in public administrations". International Journal of Information Management, Vol.26, p.102-115

Janssen, M., Joha, A., (2008), "Emerging shared service organizations and the service-oriented enterprise: Critical management issues", Strategic Outsourcing: An International Journal, Vol. 1(1), p.3549.

Janssen, M., Wagenaar, R. W. (2004). "Developing generic shared services for E-government". Electronic Journal of Electronic Government, Vol. 2(1), p.31-38.

Joo, B. (2010), "Organizational commitment for knowledge workers: The roles of perceived organizational learning culture, leader-member exchange quality, and turnover intention", Human Resource Development Quarterly, Vol. 21, p. 69-86

Judge, T. A., Thoresen, C. J., Bono, J. E., \& Patton, G. K. (2001). "The job satisfaction-job performance relationship: A qualitative and quantitative review". Psychological Bulletin, Vol. 127(3), p. 376407.

Kaplan, S. Winby S. (2009), "Organizational Models for Innovation" [White paper], Retrieved on Nov. 3, 2011 from:

http://www.innovation-point.com/Organizational\%20Models\%20for\%20Innovation.pdf

Kelloway, E. K., Gottlieb, B. H., \& Barham, L. (1999), "The source, nature, and direction of work and family conflict: A longitudinal investigation". Journal of Occupational Health Psychology, Vol.4(4), p.337-346.

Kirkman, B.L., Rosen, B., Tesluk, P.E. and Gibson, C.B. (2004), "The impact of team empowerment on virtual team performance: The moderating role of face-to-face interaction", Academy of Management Journal, Vol. 47, p. 175-92.

Koenen, J. (2006), 'SAP findet in Prag keine Arbeitskraefte:Teurer Traum vom Billiglohn', Handelsblatt Nov 22, 2006 Retrieved on Nov 7, 2011 from:

http://www.handelsblatt.com/unternehmen/it-medien/teurer-traum-vom-billiglohn/2736098.html

Konovsky, M.A, Cropanzano, R., (1991) "Perceived fairness of employee drug testing as a predictor of employee attitudes and job performance" Journal of Applied Psychology, Vol.76(5) p.698-707

Kris, A., Fahy, M. (2003), Shared service centers: Delivering value from more effective finance and business processes (Executive Briefings), Pearson Education, Prentice Hall.

Lee, T. W., Mowday, R. T. (1987). "Voluntarily leaving an organization: An empirical investigation of Steers and Mowday's model of turnover", Academy of Management Journal, Vol.30(4), p 721-743. Lemagnen, P. (2005), "SSC waves break over Europe". Oxford Intelligence

Locke, E.A. (1976), "The nature and causes of job satisfaction”, In Dunnette, M.D. (Eds.), Handbook of Industrial and Organizational Psychology, Rand McNally, Chicago, IL, p. 1297-1349.

Mael, F. and Ashforth, B.E. (1992), "Alumni and their alma mater: a partial test of the reformulated model of organizational identification", Journal of Organizational Behavior, Vol. 13(2), p.103-123.

McFerlin, D.B., Sweeney, P.D. (2001), "Cross-cultural applications of organizational justice". In R. Cropanzano (Eds.), Justice in the workplace: From theory to practice (Applied Psychology Series Vol.2) p. 67-95. Lawrence Erlbaum Associates:NJ.

Meyer, J.P. and Allen, N.J. (1997). Commitment in the workplace: theory, research, and application. Sage Publications, Thousand Oaks, California. 
Michaels, C. E., Spector, D. E. (1982), "Causes of employee turnover: A test of the Mobley, Griffeth, Hand, and Meglino model”, Journal of Applied Psychology, Vol. 67,(1), p.53- 59.

Mobley, W.H. (1977), "Intermediate linkages in the relationship between job satisfaction and employee turnover", Journal of Applied Psychology, Vol. 62(2) p.237-240

Montoya-Weiss, M., Massey, A. and Song, M. (2001), "Getting it together: Temporal coordination and conflict management in global virtual teams", Academy of Management Journal, Vol. 44, p. 1251 -62 .

Moorman, R. H. (1991). "Relationship between organizational justice and organizational citizenship behaviors: Do fairness perceptions influence employee citizenship?” Journal of Applied Psychology, Vol. 76, p845

Mowday, R.T.,Steers, R.M., Porter, L.W.(1979), “The measurement of organizational commitment”, Journal of Vocational Behavior, Vol 14, p.223-247

Nagy, M.S. (2002), “Using a single-item approach to measure facet job satisfaction”, Journal of Occupational and Organizational Psychology, Vol.75(1), p.77-86

Niehoff, B.P. and Moorman, R.H. (1993), “Justice as a mediator of the relationship between methods of monitoring and organizational citizenship behavior', Academy of Management Journal, Vol. 36 (3), p. 527-556.

Norling, P. (2001), "Call centre companies and new patterns of organizations", Economic and Industrial Democracy. Vol. 22(1) p. 155-168

O'Reilly, C. A. Caldwell, D. F. (1980), Job choice: "The impact of intrinsic and extrinsic factors on subsequent satisfaction and commitment", Journal of Applied Psychology, 65,(5), 559-565.

O'Reilly, C. A., Caldwell, D. F. (1981), "The commitment and job tenure of new employees: Some evidence of postdecisional justification”, Administrative Science Quarterly, Vol.26, 597-616.

Otter, T. (2003), "Shared Service and HR", International Association of Human Resource Information Management (IHRIM) Journal, Vol. 7(5) p.22-32

Scarpello, V., \& Campbell, J. P. (1983). "Job satisfaction: Are all the parts there?" Personnel Psychology, Vol. 36(3), p.577-600.

Smith, P. C. (1992). "In pursuit of happiness: Why study general job satisfaction?" In C. J.Cranny, P. C. Smith, \& E. F. Stone (Eds.), Job Satisfaction: Advances in Theory and Research, New York: Free Press.

Spector, P.E. (1985), "Measurement of human service staff satisfaction: Development of the job satisfaction survey", American Journal of Community Psychology, Vol.13 (6), p. 693 - 713

Stumpf, S. A., Hartman, K. (1984). "Individual exploration to organizational commitment or withdrawal", Academy of Management Journal, Vol 27,(2), 308-329.

Sutcliff, M.R. (2003), "The state of shared services", The 4th Annual Global Shared Services Conference Presentation. Retrieved May 14, 2010, from:

http://www.accenture.com.sa/NR/rdonlyres/7864AE2C-8C9B-41C6-9DF8 A81E803D01E9/0/ gssc_2003_plenary.pdf

Tett, R.P., Meyer J.P. (1993), “Job satisfaction, organizational commitment, turnover intention, and turnover: Path analyses based on meta-analytic findings" Personnel Psychology, Vol.46 (2) p.259-293

Ulbrich, F. (2006), "Improving shared service implementation: Adopting lessons from the BPR movement” Business Process Management Journal Vol.12 (2) p.191-205

Wagner, J.A. III., Hollenbeck J.R. (2005), Organizational Behavior: Securing competitive advantage. 5.ed South Western, $\mathrm{OH}$

Wanous, J. P., Reichers, A. E., and Hudy, M. J. (1997). “Overall job satisfaction: How good are single -item measures?” Journal of Applied Psychology, Vol.82(2), p. 247-252. 


\section{APPENDIX I.}

Table A. Basic Demographic Statistics of the Sample $(\mathrm{N}=124)$

\begin{tabular}{|c|c|c|}
\hline Characteristics & Frequency & $\%$ \\
\hline \multicolumn{3}{|l|}{ GENDER } \\
\hline Male & 80 & 64.5 \\
\hline Female & 44 & 35.5 \\
\hline \multicolumn{3}{|l|}{ EDUCATION } \\
\hline Associate/Vocational degree and below & 15 & 12.1 \\
\hline Bachelor degree & 54 & 43.5 \\
\hline Masters/Doctorate & 55 & 44.4 \\
\hline \multicolumn{3}{|l|}{ JOB ROLES } \\
\hline Admin / Front Office & 18 & 19.3 \\
\hline Professional & 54 & 43.6 \\
\hline Supervisory (Mid-managerial) & 25 & 20.2 \\
\hline Managerial & 21 & 16.9 \\
\hline \multicolumn{3}{|l|}{ DURATION OF EMPLOYMENT } \\
\hline $0-2$ years & 30 & 24.2 \\
\hline $2-4$ years & 54 & 43.5 \\
\hline $4-6$ years & 28 & 22.6 \\
\hline Over 6 years & 12 & 9.7 \\
\hline \multicolumn{3}{|l|}{ PARTICIPANTS' NATIONALITY } \\
\hline Asia & 24 & 19.4 \\
\hline Eastern Europe & 46 & 37.1 \\
\hline Western Europe & 33 & 26.6 \\
\hline Others & 21 & 16.9 \\
\hline TOTAL COUNTRIES REPRESENTED* & 42 & \\
\hline
\end{tabular}

Figure A. Distribution of Respondents' Nationalities

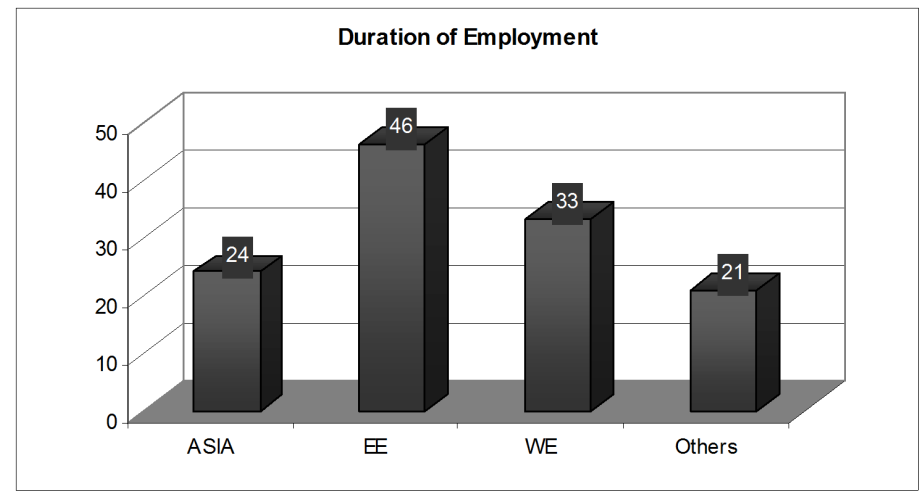

*Total Countries Represented:

ASIA: Azerbaijan, India, Malaysia, Turkey, Uzbekistan

EE: $\quad$ Albania, Bosnia, Bulgaria, Czech Republic, Greece, Hungary, Latvia, Poland, Romania, Serbia, Slovakia

WE: Austria, Belgium, Denmark, Finland, France, Germany, Italy, The Netherlands, Norway, Portugal, Spain, Sweden, UK

Others: Australia, Brazil, Chile, Colombia, Cameroon, Egypt, Ghana, Lebanon, Mauritius, Mexico, Nigeria, Tunisia, USA 


\section{APPENDIX II.}

Table B. Descriptive Statistics and Reliability Analyses for the Sample $(\mathrm{N}=124)$

\begin{tabular}{|c|c|c|c|c|c|}
\hline Factors/Items & Mean & SD & Min & Max & Cronbach \\
\hline ORG JUSTICE & 3.3298 & 0.9311 & & & 0.954 \\
\hline Distributive Justice (DJ) & 3.2871 & 0.9343 & & & 0.792 \\
\hline$\overline{\mathrm{DJ}-1}$ & 3.9839 & 1.11883 & 1.0000 & 5.0000 & \\
\hline DJ-2 & 2.7581 & 1.42207 & 1.0000 & 5.0000 & \\
\hline DJ-3 & 3.2742 & 1.23195 & 1.0000 & 5.0000 & \\
\hline DJ-4 & 2.9677 & 1.31245 & 1.0000 & 5.0000 & \\
\hline DJ-5 & 3.4516 & 1.21879 & 1.0000 & 5.0000 & \\
\hline Procedural Justice (PJ) & 3.1968 & 1.0552 & & & 0.889 \\
\hline PJ-1 & 3.2823 & 1.20676 & 1.0000 & 5.0000 & \\
\hline PJ-2 & 2.9113 & 1.39110 & 1.0000 & 5.0000 & \\
\hline PJ-3 & 3.2903 & 1.27371 & 1.0000 & 5.0000 & \\
\hline PJ-4 & 3.2500 & 1.21391 & 1.0000 & 5.0000 & \\
\hline PJ-5 & 3.2500 & 1.24695 & 1.0000 & 5.0000 & \\
\hline Interactional Justice (IJ) & 3.4274 & 1.0825 & & & 0.957 \\
\hline IJ-1 & 3.5081 & 1.27831 & 1.0000 & 5.0000 & \\
\hline $\mathrm{IJ}-2$ & 3.6694 & 1.22123 & 1.0000 & 5.0000 & \\
\hline $\mathrm{IJ}-3$ & 3.2419 & 1.32131 & 1.0000 & 5.0000 & \\
\hline $\mathrm{IJ}-4$ & 3.5161 & 1.22630 & 1.0000 & 5.0000 & \\
\hline $\mathrm{IJ}-5$ & 3.5161 & 1.23291 & 1.0000 & 5.0000 & \\
\hline IJ-6 & 3.3629 & 1.25157 & 1.0000 & 5.0000 & \\
\hline IJ-7 & 3.4032 & 1.21588 & 1.0000 & 5.0000 & \\
\hline IJ-8 & 3.3548 & 1.24413 & 1.0000 & 5.0000 & \\
\hline IJ-9 & 3.2742 & 1.31495 & 1.0000 & 5.0000 & \\
\hline ORG COMMITMENT & 3.1754 & 1.1427 & & & 0.936 \\
\hline Commitment to SSC (COMS) & 3.0968 & 1.2142 & & & 0.899 \\
\hline COMS-1 & 3.1210 & 1.40610 & 1.0000 & 5.0000 & \\
\hline COMS-2 & 3.1129 & 1.48274 & 1.0000 & 5.0000 & \\
\hline COMS-3 & 2.8871 & 1.27010 & 1.0000 & 5.0000 & \\
\hline COMS-4 & 3.2661 & 1.37403 & 1.0000 & 5.0000 & \\
\hline ORG IDENTIFICATION & 2.9871 & 1.1072 & & & 0.947 \\
\hline Identification to SSC (IDS) & 2.9742 & 1.1402 & & & 0.899 \\
\hline IDS-1 & 2.6694 & 1.26698 & 1.0000 & 5.0000 & \\
\hline IDS-2 & 3.2097 & 1.38090 & 1.0000 & 5.0000 & \\
\hline IDS-3 & 3.0726 & 1.30149 & 1.0000 & 5.0000 & \\
\hline IDS-4 & 2.9758 & 1.41113 & 1.0000 & 5.0000 & \\
\hline IDS-5 & 2.9435 & 1.39279 & 1.0000 & 5.0000 & \\
\hline TURNOVER INTENTION (T) & 3.1835 & 1.3317 & & & 0.952 \\
\hline $\mathrm{T}-1$ & 3.1048 & 1.39580 & 1.0000 & 5.0000 & \\
\hline $\mathrm{T}-2$ & 3.2581 & 1.42493 & 1.0000 & 5.0000 & \\
\hline $\mathrm{T}-3$ & 3.3065 & 1.35657 & 1.0000 & 5.0000 & \\
\hline $\mathrm{T}-4$ & 3.0645 & 1.51814 & 1.0000 & 5.0000 & \\
\hline JOB SATISFACTION (S) & 3.1210 & 1.2136 & 1.0000 & 5.0000 & \\
\hline
\end{tabular}




\section{APPENDIX III.}

Table C. Independent T-test Results*

\begin{tabular}{|c|c|c|c|c|c|c|c|}
\hline Factor / Item & Group & $\mathbf{N}$ & Mean & St.dev & d.f. & $\mathbf{t}$ & $\mathbf{p}$ \\
\hline \multirow[t]{2}{*}{ Organizational justice } & Male & 80 & 3.343 & .9184 & 122 & .208 & .835 \\
\hline & Female & 44 & 3.306 & .9732 & & & \\
\hline \multirow[t]{2}{*}{ Distributive justice } & Male & 80 & 3.295 & 1.1212 & 122 & .126 & .900 \\
\hline & Female & 44 & 3.273 & .9356 & & & \\
\hline \multirow[t]{2}{*}{ Procedural justice } & Male & 80 & 3.193 & 1.1018 & 122 & -.061 & .952 \\
\hline & Female & 44 & 3.205 & 1.0577 & & & \\
\hline \multirow[t]{2}{*}{ Interactional justice } & Male & 80 & 3.453 & 1.2200 & 122 & .350 & .727 \\
\hline & Female & 44 & 3.381 & 1.2177 & & & \\
\hline \multirow[t]{2}{*}{ Commitment to SSC } & Male & 80 & 3.100 & 1.1413 & 122 & .040 & .968 \\
\hline & Female & 44 & 3.091 & 1.1507 & & & \\
\hline \multirow[t]{2}{*}{ Identification to SSC } & Male & 80 & 2.998 & 1.1003 & 122 & .306 & .760 \\
\hline & Female & 44 & 2.932 & 1.2215 & & & \\
\hline \multirow[t]{2}{*}{ Turnover intention } & Male & 80 & 3.072 & 1.0727 & 122 & -1.26 & .210 \\
\hline & Female & 44 & 3.386 & 1.1794 & & & \\
\hline \multirow[t]{2}{*}{ Job satisfaction } & Male & 80 & 3.213 & 1.2396 & 122 & 1.134 & .259 \\
\hline & Female & 44 & 2.955 & 1.1605 & & & \\
\hline
\end{tabular}

* Equal variances assumed 